\title{
Public Information Project of the Total Solar Eclipse of November 3, 1994 in Paraná State, Brazil
}

\author{
By R.H. Trevisan
}

University of Londrina, Campus Universitário-Londrina - Paraná -CEP 86051-970, Brazil

This project had two principal objectives: to communicate safe methods to observe the Sun, so as to prevent ophthalmological accidents to people during the total solar eclipse of 3rd November 1994, and to collaborate with the primary school teachers in the science classroom, illustrating the classes, motivating the students to observe sky phenomena.

\section{Introduction}

In January 1993, a commission called "ECLIPSE 94" Executive Commission, of the Brazilian Astronomical Society was created to coordinate assistance with arrangements for observing the total solar eclipse of 3rd November 1994, that in Brazil was total in the western part of Paraná State, in Santa Catarina State and in a Rio Grande do Sul zone. Professional astronomers from Brazil and from several parts of the world were mobilized to observe this eclipse. The biggest interest in this phenomenon was because the next one of this type, in Brazil, will only occur in the year 2046, and will be visible in Paraiba State. The general coordination was done by Prof. Dr. Oscar Matsuura, from the Astronomical and Geophysical Institute of University of São Paulo.

Following the suggestion of the Working Group on Eclipses of the International Astronomical Union, this commission decided to amplify their action, assuming the articulation of a large publicity campaign about eclipses, close to the common people. Such a campaign was aimed at giving technical and astronomical information and at preventing ophthalmological accidents to people during the total solar eclipse of November 3, 1994. Utilising this fact, we decided to use this campaign to collaborate with the teachers, principally in high school, illustrating science classes, and motivating the students to observe sky phenomena. This commission was helped by people linked to official institutions that, because of vocation, count as an adequate substructure to articulate this campaign in their own regions. These people were the state coordinators (people in universities, observatories, planetariums, museums and research institutes).

\section{The General Directive of the Campaign}

The general directive of the national campaign (Matsuura, 1994) was as follows. The states of the region where the eclipse would be total (in the south of Brazil), would have a state coordinator, to coordinate the information in the region. This coordinator, would designate some Regional Supervisors, and they would designate the special monitors, to work with them in their regions. The attendance should include all the people, in town and country. The distribution of information such as the distribution of materials to observe the Sun safely, should be promoted by the special monitors, previously trained and instructed. These monitors were university students and teachers, amateur astronomers, teachers of high school, etc. Four months before the eclipse, in the winter holidays, the special monitor group would organise together a training course of three days, attended by the regional supervisors, about eclipse theory and observation using cheap and safe 
materials. The Executive Commission would give basic texts and original images to official or private organisations, to make folders, posters, booklets, etc. The coordination of the campaign at a local level, involved universities, planetariums, amateur associations, official organisations of the state and of the cities. The local coordinator organised courses to train new monitors.

\section{The Communication Campaign in Paraná State}

The beginning of the campaign in Paraná, was in March 1993, when the regional supervisor was named. The campaign followed the program in Figure 1.

Six special monitors chosen among physics students of the University worked with the state coordinator, in the general coordination. They worked 20 hours a week, and were paid by official support.

The regional supervisors chosen were: teachers from four universities of the state, educational professionals from Government Education Department of State, city hall, cultural center, high schools and physics students. There were twelve elements in Paraná State. Their function was to coordinate communication of the event in their region, forming monitors of the second and third generation, promoting courses, talks, fairs, interviews and events in general, with the collaboration of the city halls of the cities and of the Government Education Department of State, coordinated by the state coordinator of the project.

The training of the Parana regional supervisors was with all Brazilian supervisors (92 in total), and was done within the general coordination (Oscar Matsuura, and Roberto Boczko from IAG/USP). The training of these people, allowed them to achieve a "multiplier effect" in communication. The course was of 24 hours, in three days, in Chapec City (Santa Catarina), in the region of totality. All the costs were paid by the local city hall and by national research funding agencies. Each one of the 92 people, instructed about 400 new monitors in their regions.

Most of the financial support (US\$5,760) of the campaign in Paraná, was given by the Ministry of Education. This subsidy was for daily expenses, air tickets, consumables for propaganda materials and to pay the students. Besides this, we counted on the support of the Department of Physics of University of Londrina - Paraná, the telephone company, city newspaper, the Agronomic Institute and some contractors.

The Government Education Department of State worked with the eclipse state coordination through their net of 25 "Regional Centres of Teaching", localised in 25 different cities of the state. Their participation was in several ways: paying for their representatives to go to the capital of the state (Curitiba) to attend a course of about 20 hours, with the state coordinators, where they could learn all about eclipses; administering courses to primary and high school science teachers in all public schools of the state; sending notes and folders to all these teachers and schools, teaching them how to observe the eclipse safely and stimulating them to observe the eclipse with their children. The program of these courses was:

- The history of eclipses

- The phenomena of eclipses and their occurrence - local circumstances of the eclipse

- The Sun: a general view; Solar atmosphere and wind; Archaeoastronomy; Observational solar eclipse safety methods

- Didactic experiments for the solar eclipse; Observation with binoculars and small telescope

- Solar eclipse photographs

- Debate: strategy of the campaign; Interaction with the community. 
Figure 1. Program of the principal events

\begin{tabular}{|c|c|}
\hline Date & Event \\
\hline June 1993 & State coordinator designation \\
\hline July 1993 & Regional supervisor designation (twelve elements in Paraná, State) \\
\hline August 1993 & $\begin{array}{l}\text { Poster presentation in a meeting of astronomers, with the strategy } \\
\text { of the campaign }\end{array}$ \\
\hline October 1993 & $\begin{array}{l}\text { Sending submission of the eclipee project to financial organisations } \\
\text { to ask for financial support }\end{array}$ \\
\hline February 1994 & $\begin{array}{l}\text { First contact of the state coordinator with the Government } \\
\text { Education Department of State: definition of the aims of the project }\end{array}$ \\
\hline February 1994 & Special monitors and monitors of the second generation designated \\
\hline March 1994 & $\begin{array}{l}\text { Contact of the regional supervisors with the city halls of the } \\
\text { principal cities of the State }\end{array}$ \\
\hline April 1994 & Folders and posters development \\
\hline April 1994 & Starts the contact with Press \\
\hline May 1994 & $\begin{array}{l}\text { Course for regional supervisors ( } 92 \text { people), coming from seven } \\
\text { Brazilian states }\end{array}$ \\
\hline August 1994 & Start the folder distribution \\
\hline August 1994 & $\begin{array}{l}\text { Training course for special monitors ( } 25 \text { people), coming from } 25 \\
\text { different cities of the State }\end{array}$ \\
\hline September 1994 & $\begin{array}{l}\text { Training courses for science teachers in } 25 \text { cities of the state, } \\
\text { coordinated by the special monitors }\end{array}$ \\
\hline Sept/Oct. 1994 & $\begin{array}{l}\text { Fairs, expositions; poster competition by the students, and talks in } \\
\text { many cities of the State, coordinated by the regional supervisors } \\
\text { and special monitors }\end{array}$ \\
\hline October 1994 & Start the poster distribution \\
\hline October 1994 & $\begin{array}{l}\text { Journalism course specialising in Science and Technology course to } \\
\text { train journalists, with emphasis on eclipses }\end{array}$ \\
\hline October 1994 & Photos, videos and kits show \\
\hline November 1994 & $\begin{array}{l}\text { i) "See the Eclipse in the Squares"extension project in Londrina City } \\
\text { ii) "Seeing the Eclipse with the University of Londrina" extension } \\
\text { project in Foz do Iguaçu and Criciúma Cities }\end{array}$ \\
\hline December 1994 & Educational video "Eclipse 94 " to be distributed to schools \\
\hline
\end{tabular}


The objective of these courses was: to communicate the solar eclipse of November 3rd 1994; the precautions to take to observe the eclipse and the Sun; to motivate the children and the general public to observe astronomical phenomena, utilising the Universe as a laboratory. Two experiments were designed for children and ten teaching instrument kits to observe the Sun by projection. They were given to teachers who instructed their students how to use them. The kits were distributed in the schools science fairs.

The contact with the press was fundamental to the success of this project. To do this, we started the contact about one year before the eclipse. Near the date of the event, we gave a Journalism Course Specialising in Science and Technology with emphasis on eclipses to train journalists of the region, with the objective of giving accurate information to the people in a simple and didactic way, always with the orientation of a monitor, technical information about safe solar observation to prevent ophthalmological accidents.

The principal propaganda materials were: folders and posters. There were 15,000 folders inviting people to look at the eclipse, and to look safely. They were distributed to the regional supervisors in different regions, and to the Government Education Department of State to be reproduced freely. It was distributed to all professional Brazilian astronomers; universities, private schools, city halls, shopping malls, churches, associations and syndicates, business offices, etc. The posters $(1,500)$ were distributed by the monitors to the Municipal Bus Company, banks, schools, inviting people to see the "Eclipse in the Square" by projection. The "Eclipse in the Square" was a project operated in Londrina City. Big paintings were used in the squares. The number of people in the squares of Londrina City, where the totality of the eclipse was $90 \%$, was estimated to be 6,000 people.

\section{Results}

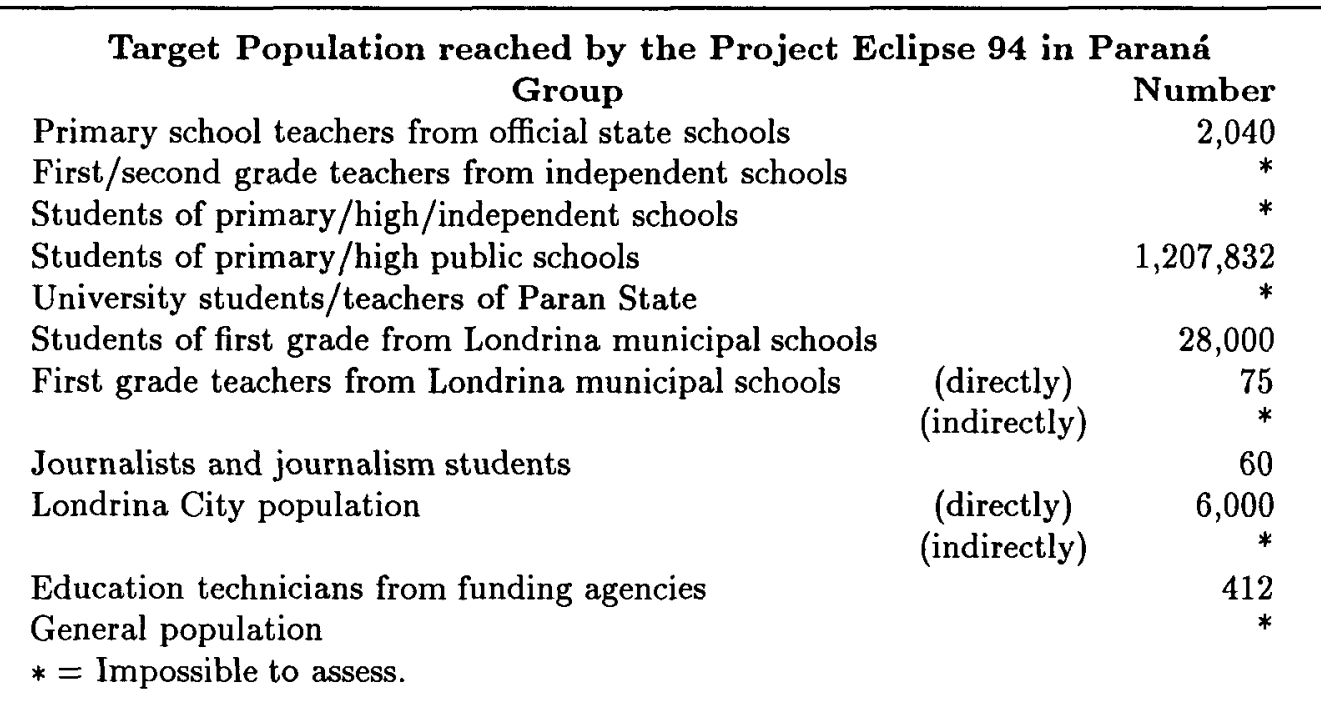

We estimate that $80 \%$ of population from south of Brazil was reached by the national project Eclipse 94.

Many students and teachers developed their own interest in astronomy. 
Information Papers Produced

Scientific education articles in authorised reviews $\quad 02$

Interviews (newspapers, TV, radio) (registered) 45

Scientific events (posters, talks, round table) 05

Talks to general public 13

We can say that the objectives of the campaign were totally reached. The two principal factors that permit us to say that are: i) the large number of articles in press and ii) no eclipse related accidents in people were reported, which is rare in a total solar eclipse.

\section{Acknowledgement}

Our thanks to the physics student Sheila Aparecida Faraco, who worked together with the general coordination of the project.

\section{REFERENCES}

Matsuura, O.The Divulgation Norms of the Eclipse 94 Brazilian Campaign, personal communication. 